\title{
Studi Histologi Kolon Ayam Broiler dengan Pemberian Suplemen Asam Butirat
}

\author{
(HISTOLOGICAL STUDY OF BROILER CHICKENS COLON GIVEN \\ BUTYRIC ACID SUPPLEMENTS)
}

\section{Zumara Mufida Hidayati $^{1 *}$, I Ketut Berata ${ }^{2}$, Ni Luh Eka Setiasih ${ }^{3}$}

\author{
${ }^{1}$ Perumahan Pondok Bedadung Indah Q.37 Jember, Jawa Timur, Indonesia 68131; \\ ${ }^{2}$ Laboratorium Patologi Veteriner, Fakultas Kedokteran Hewan Universitas Udayana, Jl. PB. \\ Sudirman Denpasar Bali, Indonesia 80225; \\ ${ }^{3}$ Laboratorium Histologi Veteriner, Fakultas Kedokteran Hewan Universitas Udayana, Jl. PB. \\ Sudirman Denpasar Bali, Indonesia 80225. \\ *Email: zumaramufida@gmail.com
}

\begin{abstract}
ABSTRAK
Tujuan penelitian untuk mengetahui pengaruh perbedaan dosis dan lama pemberian suplemen asam butirat terhadap ketebalan lapisan kolon ayam broiler. 24 ekor ayam broiler dirancang dalam penelitian pola faktorial $3 \times 4$ yaitu 3 faktor dosis suplemen $(0 ; 0,5$; dan $1 \mathrm{~g}$ suplemen $/ \mathrm{kg}$ pakan) dan faktor lama pemberian (1,2,3, dan 4 minggu). Ayam dibagi atas tiga kelompok yaitu kelompok kontrol (P1), kelompok dengan pemberian suplemen asam butirat 0,5 (P2), dan $1 \mathrm{~g}$ suplemen/kg pakan (P3). Setiap minggu, ayam broiler sebanyak dua ekor dari masing-masing kelompok dinekropsi dan diambil bagian kolonnya untuk dibuat preparat histologi menggunakan pewarnaan HE. Perubahan yang diamati meliputi ketebalan lapisan mukosa, submukosa, muskularis, dan serosa menggunakan aplikasi ZEN. Data dianalisis dengan sidik ragam dan dilanjutkan uji Duncan jika ada perbedaan yang nyata. Hasil pengukuran menunjukkan perbedaan dosis asam butirat tidak berpengaruh terhadap ketebalan lapisan kolon tetapi berpengaruh terhadap perubahan histologis kolon. Lama pemberian asam butirat berpengaruh terhadap ketebalan tunika mukosa, submukosa, muskularis, dan serosa.
\end{abstract}

Kata kunci: Ayam broiler; asam butirat; kolon; histologi

\begin{abstract}
This study aims were to determine the differences dosage and duration of butyric acid supplements on layer thickness of colon broiler chicken. The sample consisted of 24 broiler chickens. This study used a Completely Randomized Design 3x4 factorial pattern that consisted of 3 factors of supplement dosage (0; 0.5 ; and $1 \mathrm{~g}$ supplement/ $\mathrm{kg}$ of feed) and duration of administration (1,2,3 and 4 weeks). Samples were divided into 3 groups: control group (P1), group with butyric acid supplementation 0.5 (P2), and group with $1 \mathrm{~g}$ supplement / $\mathrm{kg}$ of feed (P3). Every week, two broiler chickens from each group were necropsied and the colonic tissue were taken for histologically preparations using $\mathrm{HE}$ staining. The changes observed were on the thickness of mucosal, submucosal, muscular, and serous's layer and then examined under a microscope and then calculated using ZEN applications. Data were analyzed using Analysis of Variance and followed by Duncan test if there is a significant difference. The results showed the difference in the dose of butyric acid did not affect the thickness of the colon layer but it affects on the colon histological changes. The difference in the duration of butyric acid administration affects the thickness of the tunica mucosa, submucosa, muscularis, and serosa. It is concluded that the administration of butyric acid between doses $0 ; 0,5$; and $1 \mathrm{~g} / \mathrm{kg}$ chicken food did not affect for the thickness of the mucosal, submucosal, muscularis, and serous's layer, but it affected the presence of the colon histological changes. Differences in the duration of butyric acid's administration at week 1,2,3,4 affects the thickness of the mucosal, submucosal, muscularis, and serosal's layer of broiler chicken.
\end{abstract}

Keywords: Broiler chicken; butyric acid; colon; histology 


\section{PENDAHULUAN}

Meningkatnya jumlah penduduk di seluruh dunia, termasuk Indonesia, menyebabkan permintaan akan kebutuhan protein hewani juga meningkat. Salah satu pemasok protein hewani yang banyak diminati oleh masyarakat adalah daging ayam broiler (Putra et al., 2015). Untuk meningkatkan kualitas daging yang baik diperlukan pemberian pakan yang tepat. Selain itu, pemberian perlakuan khusus oleh peternak pada ayam broiler juga diperlukan untuk meningkatkan efisiensi dalam beternak. Salah satu perlakuan khusus yang dilakukan yaitu dengan memberikan antibiotika sebagai imbuhan pakan (feed additive). Antibiotika dalam dosis sangat kecil dapat mempercepat pertumbuhan ternak (Murdiati, 1997). Namun, penggunaan antibiotika sebagai bahan aditif dalam pakan ternak telah dilarang di beberapa negara karena kemungkinan adanya residu antibiotika dan berkembangnya bakteri yang resisten terhadap antibiotika. Salah satu alternatif pengganti antibiotika sebagai feed additive ayam broiler adalah dengan memberikan suplemen asam butirat.

Asam butirat merupakan salah satu asam lemak rantai pendek atau Short Chain Fatty Acid (SCFA), yang dianggap sebagai alternatif potensial untuk menggantikan antibiotika sebagai growth promotor (Van Immerseel et al., 2005). Asam butirat sangat berperan dalam perkembangan sel epitel usus dan memiliki aktivitas bakterisidal yang tinggi sehingga berpengaruh pada peningkatan berat badan ayam broiler (Woong et al., 2015). Kolon merupakan bagian dari usus besar yang letaknya paling posterior dari sistem pencernaan selain sekum dan kloaka (Banks, 1981). Kolon berfungsi untuk menyerap air, natrium, dan mineral lain (Ganong, 1995) yang pada ayam secara histologis dindingnya sama seperti mamalia yaitu tersusun atas tunika mukosa, tunika submukosa, tunika muskularis, dan tunika serosa (Bacha and Bacha, 2012). Kolon yang baik adalah kolon yang perkembangannya sempurna dan tidak ada lapisan yang tergerus. Lapisan yang berkembang tidak sampurna atau tergerus berpengaruh terhadap ketebalan histologi kolon. Apabila perkembangan kolon tidak sempurna maka fungsi kolon tidak optimal, absorbsi terganggu dan dapat terjadi diare serta mengurangi produktivitas ayam pedaging.

Penelitian ini bertujuan untuk mengetahui pengaruh perbedaan dosis dan lama pemberian suplemen asam butirat terhadap ketebalan lapisankolon ayam broiler. Hasil penelitian ini diharapkan dapat memberikan informasi mengenai peran asam butirat terhadap perkembangan histologi kolon ayam broiler serta meningkatkan penggunaan suplemen asam butirat oleh peternak sebagai pengganti antibiotika.

\section{METODE PENELITIAN}

\section{Sampel Penelitian}

Objek yang digunakan dalam penelitian ini adalah organ kolon ayam broiler yang diberi pakan comfeed BR I yang dicampur dengan asam butirat. Penelitian ini merupakan penelitian Rancangan Acak Lengkap (RAL) pola faktorial $4 \times 3$ yaitu faktor lama pemberian (1,2,3,4 minggu) dan 3 faktor dosis suplemen (0; 0,5; dan $1 \mathrm{~g}$ suplemen/kg pakan). Masing-masing faktor dosis suplemen terdiri dari 8 ekor ayam, sehingga total jumlah ayam yang digunakan sebanyak 24 ekor. Data diambil dari pemeriksaan histologi kolon broiler yang diberi perlakuan sesuai dengan rancangan penelitian. Setiap minggu diambil 2 ekor ayam broiler dari masingmasing perlakuan untuk dinekropsi dan bagian anterior kolon organ dipotong untuk pembuatan preparat histologi.

\section{Pembuatan Preparat Histologi}

Preparat histologi kolon dibuat menggunakan metode Kiernan (2010), dengan langkah-langkah sebagai berikut: kolon difiksasi dengan direndam ke dalam larutan Buffer Neutral Formalin 10\% selama \pm 48 jam pada suhu kamar. Setelah 
difiksasi, kolon bagian anterior diiris dengan ukuran 1 x 1 x $1 \mathrm{~cm}$. Selanjutnya, sediaan didehidrasi dengan merendam ke dalam alkohol secara berturut-turut dengan konsentrasi alkohol 70\%, 80\%, 90\%, alkohol absolut I, alkohol absolut II, dengan lama masing-masing perendaman selama \pm 2 jam. Kemudian dilakukan clearing untuk membersihkan sediaan dari sisa alkohol.

Proses selanjutnya adalah embedding dan blocking. Sampel ditanam pada blok paraffin dan disimpan dalam lemari es selama 24 jam. Blok-blok paraffin tersebut kemudian dipotong menggunakan microtome dengan ketebalan 4-5 $\mu \mathrm{m}$ dan diapungkan dalam suatu alat yang berisi air (water bath) dengan suhu $60^{\circ} \mathrm{C}$. Sediaan kemudian dipindahkan ke object glass dan dikeringkan dalam suhu kamar $26-27^{\circ} \mathrm{C}$. Langkah berikutnya adalah pewarnaan sediaan dengan Hematoksilin-Eosin. Kemudian dilakukan mounting yaitu

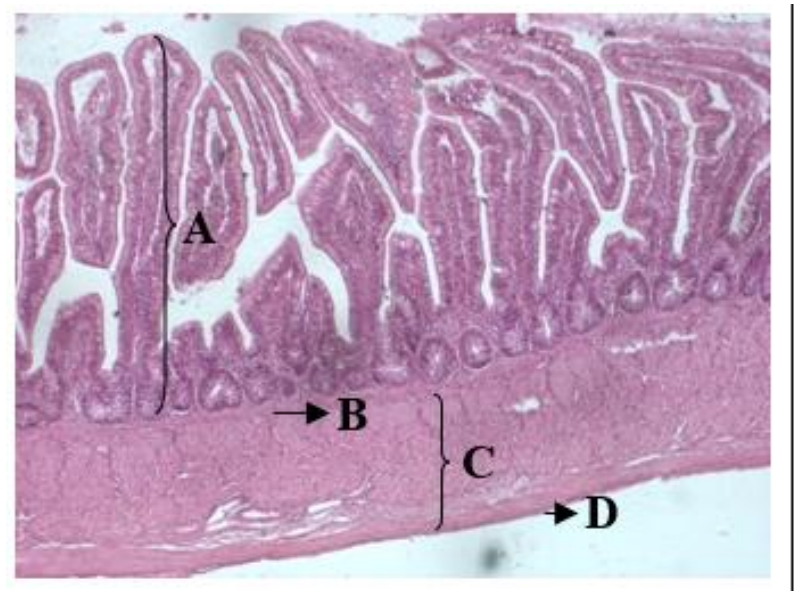

penutupan preparat dengan cover glass dengan menggunakan permount sebagai perekat.

\section{Variabel yang diukur}

Gambaran histologi yang diamati adalah tebal tunika mukosa, submukosa, muskularis, dan serosa. Masing-masing ketebalan lapisan pada lima lapang yang berbeda diukur menggunakan aplikasi ZEN. Hasil pengukuran histologi kolon masing-masing kelompok perlakuan ditabulasi dan dianalisis secara kuantitatif menggunakan sidik ragam atau Analysis of Varian (ANOVA) dan dilanjutkan dengan uji jarak berganda Duncan.

\section{HASIL DAN PEMBAHASAN}

Gambaran histologi kolon ayam broiler dan cara pengukuran lapisannya disajikan pada Gambar 1.

Gambar 1. Histologi kolon ayam broiler dan cara pengukuran lapisan (HE, 100x). (A) tunika mukosa. (B) tunika submukosa. (C) tunika muskularis. (D) tunika serosa. Pada satu lapang pandang ditarik 5 garis ukur di tempat yang berbeda di setiap lapisan. Garis kuning adalah tunika mukosa. Garis biru adalah tunika submukosa. Garis merah adalah tunika muskularis. Lingkaran ungu adalah area garis tunika serosa.

Hasil rata-rata pengukuran ketebalan tunika mukosa, submukosa, muskularis, dan serosa kolon ayam broiler yang diberi suplemen asam butirat disajikan dalam tabel berdasarkan masing-masing tunika (Tab. 1). Hasil analisis statistik menunjukkan bahwa rata-rata tebal tunika mukosa kolon ayam broiler dengan pemberian asam butirat dalam 3 perlakuan dosis $(0 ; 0,5 ;$ dan $1 \mathrm{~g} / \mathrm{kg}$ pakan) tidak berbeda nyata $(\mathrm{P}>0,05)$. Sedangkan hasil analisis statistik terhadap lama pemberian asam butirat selama 1 minggu berbeda nyata $(\mathrm{P}<0,05)$ dengan lama pemberian 2,3 , dan 4 minggu, dimana rata-rata ketebalan tunika mukosa kolon tertinggi terjadi pada minggu ke-3 (Tab 2). 
Tabel 1. Rata-rata tebal tunika mukosa kolon ayam broiler

\begin{tabular}{lccccc}
\hline \multirow{2}{*}{ Umur } & \multicolumn{5}{c}{ Dosis } \\
\cline { 2 - 6 } & 0 & $\begin{array}{c}0,5 \mathrm{~g} / 1 \mathrm{~kg} \\
\text { pakan }\end{array}$ & $\begin{array}{c}1 \mathrm{~g} / 1 \mathrm{~kg} \\
\text { pakan }\end{array}$ & Rata-rata & Sig. \\
\hline 1 minggu & 277,811 & 321,860 & 353,508 & 317,726 & $\mathrm{a}$ \\
2 minggu & 449,958 & 344,369 & 297,562 & 363,962 & $\mathrm{~b}$ \\
3 minggu & 382,021 & 298,917 & 426,113 & 369,385 & $\mathrm{~b}$ \\
4 minggu & 299,687 & 404,477 & 376,994 & 360,772 & $\mathrm{~b}$ \\
\hline Rata-rata & 352,369 & 342,405 & 363,544 & & \\
Signifikasi & $\mathrm{a}$ & $\mathrm{a}$ & $\mathrm{a}$ & & \\
\hline
\end{tabular}

Keterangan: Rata-rata tebal tunika mukosa kolon ayam dalam satuan mikron $(\mu)$. Nilai dengan huruf yang tidak sama menunjukkan perbedaan nyata $(\mathrm{P}<0,05)$.

Tabel 2. Rata-rata tebal tunika submukosa kolon ayam broiler

\begin{tabular}{cccccc}
\hline Umur & \multicolumn{5}{c}{ Dosis } \\
\cline { 2 - 6 } & 0 & $\begin{array}{c}0,5 \mathrm{~g} / 1 \mathrm{~kg} \\
\text { pakan }\end{array}$ & $\begin{array}{c}1 \mathrm{~g} / 1 \mathrm{~kg} \\
\text { pakan }\end{array}$ & Rata-rata & Sig. \\
\hline 1 minggu & 8,283 & 9,710 & 5,874 & 7,955 & $\mathrm{a}$ \\
2 minggu & 10,153 & 12,271 & 10,356 & 10,926 & $\mathrm{~b}$ \\
3 minggu & 13,848 & 8,120 & 13,145 & 11,704 & $\mathrm{~b}$ \\
4 minggu & 14,308 & 10,940 & 12,891 & 12,712 & $\mathrm{~b}$ \\
\hline Rata-rata & 11,647 & 10,260 & 10,566 & & \\
Signifikasi & $\mathrm{a}$ & $\mathrm{a}$ & $\mathrm{a}$ & & \\
\hline
\end{tabular}

Keterangan: Rata-rata tebal tunika submukosa kolon ayam dalam satuan mikron $(\mu)$. Nilai dengan huruf yang tidak sama menunjukkan perbedaan nyata $(\mathrm{P}<0,05)$.

Tabel 3. Rata-rata tebal tunika muskularis kolon ayam broiler

\begin{tabular}{|c|c|c|c|c|c|}
\hline \multirow[b]{2}{*}{ Umur } & \multicolumn{5}{|c|}{ Dosis } \\
\hline & 0 & $\begin{array}{c}0,5 \mathrm{~g} / 1 \mathrm{~kg} \\
\text { pakan }\end{array}$ & $\begin{array}{c}1 \mathrm{~g} / 1 \mathrm{~kg} \\
\text { pakan }\end{array}$ & Rata-rata & Sig. \\
\hline 1 minggu & 148,770 & 169,131 & 153,785 & 157,228 & $\mathrm{a}$ \\
\hline 2 minggu & 327,964 & 305,944 & 261,650 & 298,519 & b \\
\hline 3 minggu & 323,775 & 253,117 & 303,795 & 293,562 & b \\
\hline 4 minggu & 327,311 & 327,716 & 320,219 & 325,082 & $\mathrm{~b}$ \\
\hline Rata-rata & 281,954 & 263,977 & 259,598 & & \\
\hline Signifikasi & $\mathrm{a}$ & $\mathrm{a}$ & $\mathrm{a}$ & & \\
\hline
\end{tabular}

Keterangan: Rata-rata tebal tunika muskularis kolon ayam dalam satuan mikron $(\mu)$. Nilai dengan huruf yang tidak sama menunjukkan perbedaan nyata $(\mathrm{P}<0,05)$.

Hasil analisis statistik menunjukkan bahwa rata-rata tebal tunika submukosa kolon ayam broiler dengan pemberian asam butirat dalam 3 perlakuan dosis $(0 ; 0,5$; dan $1 \mathrm{~g} / \mathrm{kg}$ pakan) tidak berbeda nyata $(\mathrm{P}>0,05)$. Hasil analisis statistik terhadap lama pemberian asam butirat selama 1 minggu sangat berbeda nyata $(\mathrm{P}<0,01)$ dengan pemberian selama 2 , 3, dan 4 minggu, dimana rata-rata ketebalan tunika submukosa kolon tertinggi terjadi pada minggu ke-4 (Tab 3). Sementara hasil analisis statistik menunjukkan bahwa ratarata tebal tunika muskularis kolon ayam broiler dengan pemberian asam butirat dalam 3 perlakuan dosis $(0 ; 0,5$; dan $1 \mathrm{~g} / \mathrm{kg}$ pakan) tidak berbeda nyata $(\mathrm{P}>0,05)$. Hasil analisis statistik terhadap lama pemberian asam butirat selama 1 minggu sangat berbeda nyata $(\mathrm{P}<0,01)$ dengan pemberian selama 2,3, dan 4 minggu. Rata-rata ketebalan tunika muskularis kolon tertinggi terjadi pada minggu ke-4 (Tab 4). 
Tabel 4. Rata-rata tebal tunika serosa kolon ayam broiler

\begin{tabular}{cccccc}
\hline & \multicolumn{5}{c}{ Dosis } \\
\cline { 2 - 6 } Umur & 0 & $\begin{array}{c}0,5 \mathrm{~g} / 1 \mathrm{~kg} \\
\text { pakan }\end{array}$ & $\begin{array}{c}1 \mathrm{~g} / 1 \mathrm{~kg} \\
\text { pakan }\end{array}$ & Rata-rata & Sig. \\
\hline 1 minggu & 3,438 & 3,440 & 3,371 & 3,416 & $\mathrm{a}$ \\
2 minggu & 6,468 & 7,824 & 5,335 & 6,542 & $\mathrm{~b}$ \\
3 minggu & 6,521 & 5,296 & 4,146 & 5,311 & $\mathrm{c}$ \\
4 minggu & 8,891 & 5,539 & 8,067 & 7,498 & $\mathrm{c}$ \\
\hline Rata-rata & 6,329 & 5,517 & 5,229 & & \\
Signifikasi & $\mathrm{b}$ & $\mathrm{ab}$ & $\mathrm{a}$ & & \\
\hline
\end{tabular}

Keterangan: Rata-rata tebal tunika serosa kolon ayam dalam satuan mikron $(\mu)$. Nilai dengan huruf yang tidak sama menunjukkan perbedaan nyata $(\mathrm{P}<0,05)$.

Tabel 5. Rata-rata total ketebalan lapisan kolon ayam broiler

\begin{tabular}{cccccc}
\hline & \multicolumn{5}{c}{ Dosis } \\
\cline { 2 - 6 } Umur & 0 & $\begin{array}{c}0,5 \mathrm{~g} / 1 \mathrm{~kg} \\
\text { pakan }\end{array}$ & $\begin{array}{c}1 \mathrm{~g} / 1 \mathrm{~kg} \\
\text { pakan }\end{array}$ & Rata-rata & Sig. \\
\hline 1 minggu & 438,302 & 504,142 & 516,538 & 486,327 & $\mathrm{a}$ \\
2 minggu & 794,544 & 670,408 & 574,903 & 679,951 & $\mathrm{~b}$ \\
3 minggu & 726,165 & 565,423 & 747,198 & 679,595 & $\mathrm{~b}$ \\
4 minggu & 650,197 & 748,672 & 718,170 & 705,679 & $\mathrm{~b}$ \\
\hline Rata-rata & 652,301 & 622,161 & 639,202 & & \\
Signifikasi & $\mathrm{a}$ & $\mathrm{a}$ & $\mathrm{a}$ & & \\
\hline
\end{tabular}

Keterangan: Rata-rata total tebal lapisan kolon ayam dalam satuan mikron $(\mu)$. Nilai dengan huruf yang tidak sama menunjukkan perbedaan nyata $(\mathrm{P}<0,05)$.

Hasil analisis statistik menunjukkan bahwa rata-rata tebal tunika serosa kolon ayam broiler dengan pemberian asam butirat dalam 3 perlakuan dosis $(0 ; 0,5$; dan $1 \mathrm{~g} / \mathrm{kg}$ pakan) tidak berbeda nyata $(\mathrm{P}>0,05)$. Hasil analisis statistik terhadap lama pemberian asam butirat selama 1 minggu berbeda nyata $(\mathrm{P}<0,01)$ dengan pemberian selama 2, 3, dan 4 minggu. Namun, pemberian selama 3 dan 4 minggu tidak berbeda nyata $(\mathrm{P}>0,05)$. Rata-rata ketebalan tunika serosa kolon tertinggi terjadi pada minggu ke-4 (Tab 5).

Hasil analisis statistik menunjukkan bahwa rata-rata total tebal lapisan kolon ayam broiler dengan pemberian asam butirat dalam 3 perlakuan dosis $(0 ; 0,5$; dan $1 \mathrm{~g} / \mathrm{kg}$ pakan) tidak berbeda nyata $(\mathrm{P}>0,05)$. Sedangkan hasil analisis statistik terhadap lama pemberian asam butirat selama 1 minggu sangat berbeda nyata $(\mathrm{P}<0,01)$ dengan pemberian selama 2,3 , dan 4 minggu. Rata-rata total ketebalan lapisan kolon tertinggi terjadi pada minggu ke-4.
Ketebalan tunika mukosa kolon ayam broiler akibat perbedaan dosis asam butirat diperoleh rata-rata yaitu 352,369 $\pm 95,345$ $\mu \mathrm{m}$ pada kontrol (P1), 342,405 $\pm 77,617 \mu \mathrm{m}$ pada perlakuan (P2), dan 363,544 \pm $101,491 \mu \mathrm{m}$ pada perlakuan (P3). Hasil ini menunjukkan pemberian asam butirat dalam beberapa dosis tidak memberikan pengaruh terhadap tebal tunika mukosa kolon $(\mathrm{P}>0,05)$. Hasil ini berbeda dengan penelitian yang dilakukan oleh Kaczmarek et al. (2015) bahwa pemberian asam butirat dalam bentuk kapsul berpengaruh nyata terhadap ketebalan tunika mukosa ileum $(\mathrm{P}<0,05)$ yang ditandai dengan menipisnya tunika mukosa ileum. Hal ini kemungkinan terjadi karena adanya perbedaan organ dan bentuk sediaan asam butirat yang digunakan sehingga hasilnya pun berbeda. Hal ini didukung oleh pernyataan Zaleski et al. (2013) bahwa asam butirat cepat diserap pada saluran cerna bagian atas sehingga kadarnya menurun di saluran cerna bagian bawah. Selain itu, penggunaan bentuk 
kapsul untuk membungkus asam butirat menyebabkan penyerapannya berjalan lambat sehingga keberadaannya di saluran cerna pun semakin lama. Meski hasil analisa statistik tidak menunjukkan adanya pengaruh nyata, namun jika dilihat secara rata-rata pada perlakuan, (P2) $(0,5 \mathrm{~g} / \mathrm{kg}$ pakan) memiliki tebal tunika mukosa paling rendah yang menunjukkan bahwa pemberian asam butirat $0,5 \mathrm{~g} / \mathrm{kg}$ pakan berpengaruh paling baik terhadap tunika mukosa kolon. Hal ini dikarenakan pemberian asam butirat $0 \mathrm{~g} / \mathrm{kg}$ pakan dan 1 $\mathrm{g} / \mathrm{kg}$ pakan menyebabkan tunika mukosa menjadi lebih tebal dimana semakin tebal tunika mukosa pada usus mengakibatkan menurunnya efisiensi kerja dan penyerapan nutrisi pada usus, sesuai dengan pernyataan Teirlynck et al. (2009).

Ketebalan tunika mukosa mengalami peningkatan seiring bertambahnya umur.
Hasil pengukuran menunjukkan tunika mukosa pada minggu ke-2 dan ke-3 memiliki ketebalan lebih besar dari pada tunika muskularis di minggu yang sama. Hal ini terjadi karena adanya susunan padat serat kolagen yang sangat baik pada lamina propria sehingga berpengaruh terhadap ketebalan tunika mukosa tersebut (Dehkordi dan Ghahremani, 2015).

Meskipun pemberian asam butirat dalam beberapa dosis tidak berpengaruh terhadap tebal tunika mukosa $(\mathrm{P}>0,05)$, namun jika dilihat dari gambaran histologinya, nampak pada perlakuan (P3) di minggu ke-4 vili terlihat mengalami erosi epitel dan nekrosis. Hal ini membuktikan pemberian asam butirat dalam jumlah banyak akan mengurangi efek positif yaitu memicu sitotoksitas dan apoptosis di berbagai tipe sel sesuai dengan pernyataan Ochiai dan Ochiai (2009).

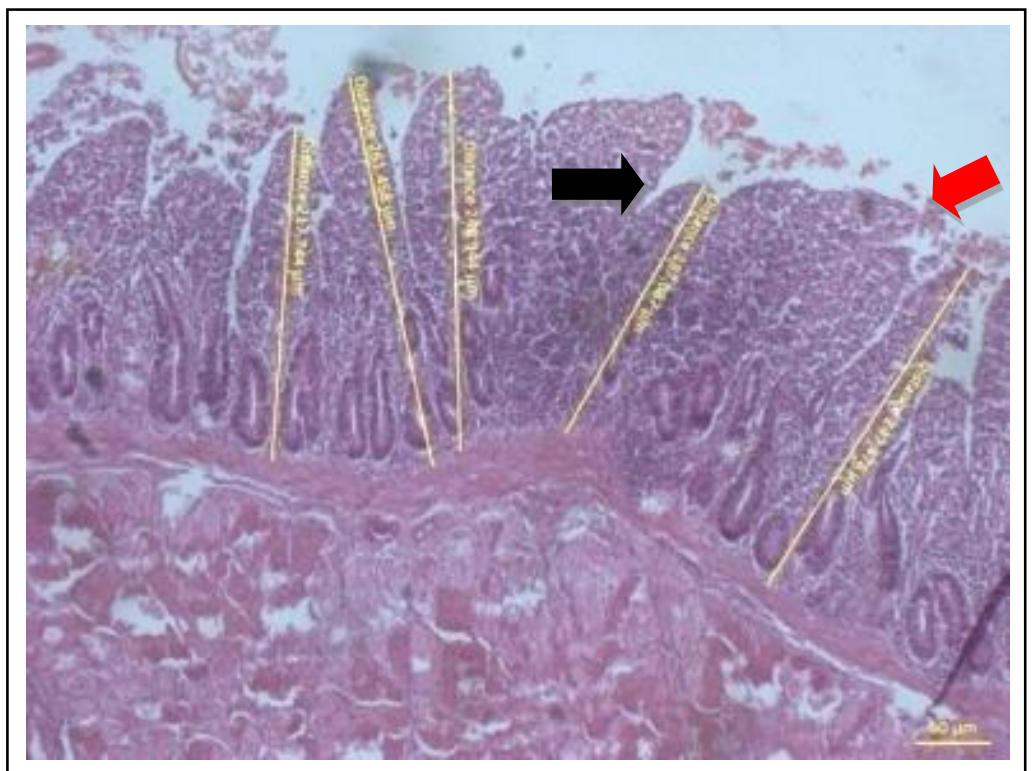

Gambar 2. Histologi tunika mukosa kolon ayam broiler perlakuan $1 \mathrm{~g} / \mathrm{kg}$ pakan pada minggu ke-4 (HE, 100x). Garis kuning adalah tinggi vili yang diukur mewakili ketebalan tunika mukosa. Erosi epitel (panah hitam) dan nekrosis (panah merah) pada tunika mukosa.

Rerata tebal tunika submukosa pada masing-masing perlakuan adalah 11,647 \pm 4,332 $\mu \mathrm{m}$ untuk kontrol (P1), 10,260 \pm $3,588 \mu$ m untuk perlakuan (P2), dan 10,566 \pm 4,444 $\mu \mathrm{m}$ untuk perlakuan (P3). Ini menunjukkan bahwa pemberian asam butirat dalam beberapa dosis tersebut tidak berpengaruh terhadap tebal tunika submukosa kolon. Hal ini terjadi karena tidak adanya salah satu reseptor asam lemak bebas pada tunika submukosa kolon, sesuai dengan penelitian Karaki dan Kuwahara (2010) bahwa tidak ditemukannya salah satu reseptor asam lemak bebas pada tunika submukosa dan 
muskularis kolon tikus pada pemeriksaan menggunakan metode Western-Blott.

Ketebalan tunika submukosa terhadap perbedaan lama pemberian asam butirat pada minggu ke-1 berbeda nyata $(\mathrm{P}<0,05)$ dengan minggu ke-2,3, dan 4. Pada minggu pertama, rata-rata tebal tunika submukosa kolon ayam broiler hanya 7,955 $\pm 3,562$. Pada minggu ke-2,3, dan 4 ketebalan tunika submukosa mengalami peningkatan dan puncak tertinggi terjadi pada minggu ke-4. Hal ini menunjukkan bahwa ketebalan tunika submukosa meningkat seiring bertambahnya usia. Hasil ini didukung oleh pernyataan bahwa tunika submukosa terlihat sebagai lapisan tipis dan lebih tipis bahkan nyaris tidak nampak pada umur muda.

Terjadi penurunan ketebalan tunika muskularis akibat pemberian asam butirat. Hal ini sesuai dengan pernyataan Adil et al. (2010) bahwa pemberian asam butirat 3\% menurunkan ketebalan muskularis di semua bagian usus halus. Berkurangnya ketebalan lapisan muskularis berdampak positif bagi saluran cerna sebagaimana pernyataan Khan dan Iqbal (2016) bahwa penurunan ketebalan muskularis meningkatkan kinerja pencernaan dan penyerapan nutrisi. Berbeda halnya dengan pengaruh lama pemberian asam butirat terhadap tebal tunika muskularis. Hasil analisis statistik menunjukkan adanya pengaruh yang sangat nyata $(\mathrm{P}<0,01)$. Tebal tunika muskularis pada minggu ke-1 berbeda nyata dengan ketebalan pada minggu ke-2,3, dan 4, dimana terjadi peningkatan ketebalan di minggu ke-2 dan 4. Pada minggu ke-4 merupakan puncak tertinggi rata-rata tebal tunika muskularis yaitu 325,082 $\pm 74,193$ $\mu \mathrm{m}$. Adanya peningkatan ketebalan tunika muskularis yang terlihat sepanjang pertambahan umur mungkin disebabkan oleh meningkatnya beban kerja otot akibat menurunnya koordinasi syaraf sebagai hasil dari hilangnya sel syaraf karena pertambahan umur, sebagaimana Baum et al. (2007).
Hasil pengukuran rata-rata tebal tunika serosa terhadap perbedaan dosis asam butirat tidak ada perbedaan nyata $(\mathrm{P}>0,05)$ antar perlakuan. Hal ini menunjukkan bahwa pemberian asam butirat dalam beberapa dosis tersebut tidak berpengaruh terhadap tebal tunika serosa kolon ayam broiler. Hasil ini sesuai dengan penelitian Fernandes et al. (2014b) bahwa penambahan asam organik dalam pakan tidak berpengaruh terhadap morfometri lapisan dinding saluran pencernaan.

Adanya pengaruh nyata $(\mathrm{P}<0,01)$ juga ditunjukkan oleh pengaruh lama pemberian asam butirat terhadap rata-rata tebal tunika serosa ayam broiler. Minggu ke-1 berbeda nyata dengan minggu ke-2,3, dan 4 $(\mathrm{P}<0,05)$, namun minggu ke-2 dan 4 tidak menunjukkan pengaruh nyata $(\mathrm{P}>0,05)$. Pada minggu ke-4 merupakan puncak tertinggi ketebalan tunika serosa yaitu $7,498 \pm 2,718 \mu \mathrm{m}$. Hal ini sesuai dengan pernyataan Hamedi et al. (2013) bahwa terjadi perubahan lapisan seiring pertambahan umur terutama selama periode prepubertal dan mencapai tingkat tertinggi saat pubertas.

Ketebalan total lapisan kolon ayam broiler tidak dipengaruhi oleh dosis. Kolon ayam yang diberi pakan tanpa tambahan asam butirat (P1) dan kolon ayam dengan penambahan asam butirat $1 \mathrm{~g} / \mathrm{kg}$ pakan (P3) memiliki ketebalan lebih tinggi dari pada kolon ayam dengan penambahan asam butirat $0,5 \mathrm{~g} / \mathrm{kg}$ pakan. Hal ini mengindikasikan bahwa lapisan dinding kolon pada perlakuan (P2) tersebut mengalami hipoplasia karena menurunnya proliferasi sel. Proliferasi terjadi untuk mengganti sel yang hilang karena nekrosis atau apoptosis (Comalada et al., 2006). Lapisan dinding kolon pada perlakuan (P2) tunika yang paling sedikit mengalami kerusakan, sehingga tidak banyak terjadi proliferasi sel. Keadaan ini sesuai dengan pernyataan Cassidy (1984) bahwa hipoplasia terjadi sebagai respon akibat sedikitnya kerusakan pada jaringan intestinal. Sehingga pemberian asam butirat 
0,5 g/kg pakan berpengaruh paling baik terhadap jaringan kolon.

Ketebalan lapisan kolon ayam broiler terhadap lama pemberian asam butirat menunjukkan adanya perbedaan yang nyata $(\mathrm{P}<0,05)$. Tebal total lapisan kolon mengalami peningkatan pada minggu ke-1 dan ke-2, namun tidak ada peningkatan di minggu ke-3 bahkan cenderung mengalami sedikit penurunan. Hal ini menunjukkan lapisan kolon berkembang pesat pada minggu-minggu awal kehidupan sesuai dengan pernyataan Zavarize et al. (2012) bahwa perkembangan biokimia dan morfologi serta pematangan usus ayam broiler terjadi pada umur 10 hari pertama. Selain itu, tidak adanya peningkatan ketebalan total lapisan kolon pada minggu ke-3 dapat disebabkan penurunan laju pertumbuhan vili pada tunika mukosa kolon, sebagaimana pernyataan Uni et al. (1996) bahwa ukuran vili meningkat tajam pada usia $1-2$ hari, kemudian laju pertumbuhannya menurun perlahan, dan stagnan pada usia sekitar $5-10$ hari setelah menetas, sehingga hal itu berpengaruh terhadap ketebalan total lapisan kolon tersebut.

Asam butirat telah terbukti sebagai sumber energi untuk aktivitas normal dan pertumbuhan kolonosit (Comalada et al., 2006). Selain itu, asam butirat berpengaruh terhadap fungsi selular yang berhubungan dengan kesehatan saluran cerna seperti menghambat peradangan dan karsinogenesis, menguatkan komponen dari sistem pertahanan kolon dan mengurangi stress oksidatif (Hamer et al., 2008), serta mencegah dan menghambat pertumbuhan kanker kolon (Canani et al., 2011). Pemberian asam butirat dalam beberapa dosis tidak berpengaruh terhadap ketebalan total lapisan kolon ayam broiler. Hal ini disebabkan kemampuan asam butirat dalam menyediakan energi untuk pertumbuhan epitel tidak begitu berpengaruh jika saluran cerna dalam keadan normal (sehat) sesuai dengan pernyataan Liu et al. (2013). Pada sel normal asam butirat hanya berperan dalam menjaga keseimbangan proliferasi dan regenerasi selnya saja. Hal ini sejalan dengan pernyataan Comalada et al. (2006) bahwa seluruh asam lemak rantai pendek tidak berpengaruh terhadap proliferasi, viabilitas, dan diferensiasi pada sel normal, tetapi berpengaruh terhadap sel yang menyimpang, yaitu dengan menghambat proliferasi dan menginduksi apoptosis. Meskipun pemberian asam butirat dalam beberapa dosis tidak berpengaruh nyata terhadap tebal lapisan kolon, namun penelitian ini menunjukkan bahwa pemberian asam butirat $0,5 \mathrm{~g} / \mathrm{kg}$ pakan berpengaruh paling baik terhadap kolon, ditandai dengan paling tipisnya lapisan kolon pada perlakuan (P2) tersebut. Hasil ini tidak sesuai dengan pernyataan bahwa semakin tebal histologi kolon maka semakin baik pula performanya, namun sesuai dengan Teirlynck et al. (2009), karena ternyata semakin tebal lapisan kolon tidak selalu mengindikasikan dampak positif bagi tubuh, sebagaimana pernyataan Fernandes et al. (2014a) bahwa penebalan usus halus atau usus besar bisa jadi disebabkan karena adanya neoplasia, peradangan, infeksi, atau kondisi iskemik.

\section{SIMPULAN}

Pemberian asam butirat dosis $0 ; 0,5$; dan $1 \mathrm{~g} / \mathrm{kg}$ pakan tidak berpengaruh terhadap ketebalan, tetapi berpengaruh terhadap gambaran histologis kolon. Lama pemberian asam butirat pada minggu ke1,2,3, dan 4 berpengaruh terhadap ketebalan tunika mukosa, submukosa, muskularis, dan serosa kolon ayam broiler.

\section{SARAN}

Perlu dilakukan penelitian lanjutan tentang mekanisme interaksi asam butirat terhadap jaringan kolon ayam broiler secara keseluruhan dan pengaruhnya terhadap jaringan kolon pada kurun waktu pemberian yang lebih lama, agar dapat diketahui lebih lanjut dampak yang ditimbulkan. 


\section{UCAPAN TERIMAKASIH}

Penulis mengucapkan terima kasih kepada Dekan FKH Unud dan Laboratorium Patologi Veteriner serta semua pihak yang telah membantu dalam penyelesaian penelitian ini.

\section{DAFTAR PUSTAKA}

Adil S, Tufail B, Gulam AB, Masood S, Manzoor R. 2010. Effect of dietary supplementation of organic acids on performance, intestinal histomorphology, and serum biochemistry of broiler chicken. Vet. Med. Int. 2010(479485): 1-7.

Bacha WJ, Bacha LM. 2012. Color atlas of veterinary histology. $3^{\text {rd }} \mathrm{Ed}$. UK, John Wiley \& Sons, Ltd.

Banks J. 1981. Applied veterinary histology. London, Williams and Wilkins Baltmore. Pp: 102.

Baum B, Meneses F, Kleinschmidt S, Nolte I, Trautwein MH. 2007. Age-related histomorphologic changes in the canine gastrointestinal tract: A histologic and imunohistologic study. World $J$. Gastroenterol. 13(1): 152-157.

Canani RB, Costanzo MD, Leone L, Pedata M, Meli R, Calignano A. 2011. Potential beneficial effects of butyrate in intestinal and extraintestinal diseases. World J. Gastroenterol. 17(12): 1519-1528.

Cassidy MM, Fitzpatrick LR, Vahouny GV. 1984. The effect of fiber in the postweaning diet on nutritional and intestinal morphological indices in the rats. $2^{\text {nd }}$ Washington Symp. Dietary Fiber.

Comalada M, Bailon E, Villoslada ODHFL, Xaus J, Zarzuelo A, Galvez J. 2006. The effects of short-chain fatty acids on colon epithelial proliferation and survival depend on the cellular phenotype. J. Cancer Res. Clin. Oncol. 132: 487-497.

Dehkordi RF, Ghahremani P. 2015. Developmental study of rectum in broiler chicken: A stereological and morphometrical study. Vet. Res. Forum. 7(1): 41-45.

Fernandes BCS, Martins MRFB, Mendes AA, Milbradt EL, Sanfelice C, Martins BB, Aguiar EF, Bresne C. 2014. Intestinal integrity and performance of broiler chickens fed a probiotic, a prebiotic, pr an organic acid. Braz. J. Poult. Sci. 16(4): 417-424.

Fernandes T, Oliveira MI, Castro R, Araujo B, Viamonte B, Cunha R. 2014. Bowell wall thickening at CT: simplifying the diagnosis. Insights Imaging. 5: 195208.

Ganong WF. 1995. Fisiolofi kedokteran. Edisi 14. Jakarta, Penerbit Buku Kedokteran EGC.

Hamedi S, Shomali T, Akbarzadeh A. 2013. Prepubertal and pubertal caecal wall histology in Japanese quails (Coturnix coturnix japonica). Bulgarian J. Vet. Med. 16(2): 96- 101.

Hamer HM, Jonkers D, Venema K, Sanvhoutvin S, Troost FJ, Brummer RJ. 2008. Review Article: the role of butyrate on colonic function. Aliment. Pharmacol. Ther. 27: 104-119.

Karaki S, Kuwahara A. 2010. Roles of Short-Chain Fatty Acids and their Receptor in Colonic Motility. Biosci. Microflora. 29(1): 31-40.

Khan SH, Iqbal J. 2016. Recent advances in the role of organic acids in poultry nutrition. J. Appl. Anim. Res. 44(1): 359-369.

Liu W, Yang Y, Zhang J, Gatlin DM, Ringo E, Zhou Z. 2014. Effect of dietary microencapsulated sodium butyrate on growth, intestinal mucosal morphology, immune response and adhesive bacteria in juvenile common carp (Cyprinus carpio) pre-fed with or without oxidised oil. British J. Nutr. (112): 1529.

Murdiati TB. 1997. Pemakaian antibiotika dalam usaha peternakan. Wartazoa. 6(1): 18-20. 
Ochiai K, Ochiai TK. 2006. Effect of butyric acid on the periodontal tissue. Jap. Dental Sci. Rev. 45: 75-82.

Putra IGNY, Sudarma M, Djelantik AAAW. 2015. Faktor-faktor yang mempengaruhi masyarakat membeli daging ayam boiler di Kabupaten Bangli. E-J. Agrib. Agrowisata. 4 (1): 47-55.

Teirlynck E, Bjerrum L, Eeckhaut V, Huygebaert G, Pasmans F, Haesebrouck F, Dewulf J, Ducatelle R, Van Immersel F. 2009. The cereal type in feed influences gut wall morphology and intestinal immune cell infiltration in broiler chickens. British J. Nutr. 102: 1453-1461.

Uni Z, Noy Y, Sklan D. 1996. Developmental parameters of th small intestines in heavy and light strain chicks pre and post-hatch. British Poult. Sci. 36: 63-71.
Van Immerseel F, Boy ENF, Gantois I, Timbermont L, Bohez L, Pasmans F, Haesebrouck F, Ducatelle R. 2005. Supplementation of coated butyric acid in the feed reduces colonization and shedding of Salmonella in poultry. Poult. Sci. 84: 1851-1856.

Woong KJ, Hyuk KJ, Yong KD. 2015. Dietary organic acids for broiler chickens: a review. Rev. Colomb. Cienc. Pecuar. 28(2): 109-123.

Zaleski A, Banaszkiewicz A, Walkowiak J. 2013. Butyric acid in irritable bowel syndrome. Prz. Gastroenterol. 8(6): 350-353.

Zavarize KC, Sartori JR, Gonzales E, Pezzato AC. 2012. Morphological changes of the intestinal mucosa of broilers and layers as affected by fasting before sample collection. Braz. J. Poult. Sci. 14(1): 21-25. 